УАK (UDC) 008:130.2:17.026:502.31

DOI: 10.26565/2226-0994-2019-60-8

Samuel Akpan Bassey

\title{
“ANTHROPOHOLISM” AS AN AUTHENTIC TOOL FOR ENVIRONMENTAL MANAGEMENT
}

Ever since nonhuman entity and the environment became a major ethical issue, anthropocentric worldviews have been blamed for all that is morally wrong about our dealings with nature. Those who regard themselves as non-anthropocentrists/holistic scholars typically assume that the West's anthropocentric axiologies and ontologies stir all of the environmental degradations associated with human species. In contrast, a handful of environmental philosophers aver that anthropocentrism is entirely acceptable as a foundation for environmental ethics as human's perspective cannot be entirely removed from the decision-making process. They often argue that is it possible for the man to act responsibly towards the environment for human's sake and its future generation. Thus there is an ever-present tension between anthropocentrism and holism, with each side trying to oust talk each other. In my opinion, those extreme views are lump sided, as such lack room for tolerance. The thrust of this paper is to bridge the gap within these ethical theories with the theory of "anthropoholism". Anthropoholism is a theory in environmental ethics that acknowledges man (anthropo) central role; perspective, place in eco-system as well as ontology but argues that despite this position, Man is just a part of nature, such that he cannot exist independently of the environment, or cannot be understood without reference to the environment. With this, the theory of anthropoholism is able to bridge the gap between the two extreme views by stating the obvious and explaining the connection between the two extreme views.

Keywords: Anthropocentricism, Anthropoholism, African Communalism, Environment.

\section{Introduction}

Modifying the relationship amongst humans and nature is standout amongst the basic issues confronting human societies which must be managed properly. With the expanding decay of our ecological world, coupled with the recent disturbing report released by the UN's IPCC (Intergovernmental Panel on Climate Change) on a new level of global warming caused by climate change in the year 2018, an environmental emergency is now required [Watts, 2018]. Most individuals now understand that we can't depend on financial and legal techniques alone to tackle the issue of environmental decadence; this implies that people now have to be morally responsible towards the environment. It is only after we have embraced a proper disposition and mindset towards nature and have also set up the right moral relationship between individuals and nature, that can we have the capacity to love and regard nature with honesty.

Humans could now boast of space travel, internet, cars and other kinds of unimaginable technological achievement that once seems unachievable, however, these technological breakthroughs somewhat pose dangers to human life as well as other beings within the environment, and as well caused environmental degradation. Humans now find himself trying to solve the catastrophic in which he brought upon himself through his ingenuity.

This could explain why Heidegger is so critical of Western metaphysics and thinks questioning the essence of technology will actually help us as Dasein have a free relationship with technology as well as the environment. The understanding of this free relationship requires that humans first re-examine what it means to be human and how it is that humans come to understand the world around him through his practical experience and mindset. Ultimately, by grounding his notion of ethics within the sphere of ontology, Heidegger envisioned human as Dasein in a free relationship with modern technology and the environment at large as one that will require a completely different attitude of being-in-the-world [Heidegger, 1993].

(C) Bassey S. A., 2019. 
However, I think such "attitude" should not be on one embed in strong anthropocentric connotations, because of its supremacy and dominating mentality towards technology and the environment. "Strong Anthropocentricism" acknowledges man at the center of the universe and further allude that other beings within the environment are of instrumental value to man. Strong anthropocentric attitude has been blamed for man's dominant tendencies towards other beings within the environment, which have in turn led to environmental decadence. A similar view is seen in Eurocentric attitude, a belief that Europeans are supreme, which in turn led to racism, colonialism, and subjugation of other human persons. However, if man endeavors to live in peace and fulfill his potentials with his fellow species being as well as other beings within the environment, there is a dire need to reject every supremacy ideology, enact ethics advocating tolerance within human society and the environment large.

We cannot deny human role within environmental ethics; be it human perspective, ideology or rather man central position within the environment, which could easily be translated to "anthropocentrism". Nevertheless, this paper argues that it will be a futile venture to attempt a strict non-anthropocentric environmental ethics as human point of view will always play in. Furthermore, one thing that makes environmental ethics possible is man's obligation towards the community and the environment. This implies that if a particular ethics requires a being to put other beings into consideration, if an ethic is a guide to action, then that become the beings own ends. This is what Frederick Ferré called "perspectival anthropocentrism"; which for me represents weak anthropocentrism.

Weak anthropocentrism acknowledges human central position in thought process, obligatory position, but advocates that human alludes to moral dispositions and theory as to not transgress this position into the egoistic and dominating tendency on the environment. This is plausible for environmental ethics but incomplete if it does not attempt to look at the environment holistically. This is because it is only within holistic environmental ethics we can understand the interdependence of being and the significance of all beings to the environment; as such the existence of any being is hinged on the whole.

Also, extreme holistic position would be one-sided if it does not acknowledge the role of man (a part) in the holism. This is also because the interests of a whole are reducible to the interests of its parts, as such the collective responsibility of the whole is also the responsibility of the part in that whole. This as such explains that the part has an important role to play within the whole.

To explain the above vividly, this paper presents a theory called "anthropoholism" which attempts to bridge the gap between both anthropocentric as well as the holistic environmental ethic. The theory accommodates the role of "human" (the individual' as well as "individuality of persons") within the thought process, environment as well as ontology but also accommodates the communal holistic spirit of man being a part of the whole as such cannot exist independently of the whole or fulfill any potential outside the whole. This paper avers that such disposition should be an underlying rationale behind man's actions and deliberations as far as the environment is concerned.

\section{The Notion of Anthropoholism}

The concept Anthropoholism is made of two words: From the Greek word anthropos "man, human being" and also "Holism" which is often used to represents all of the wholes' in the universe. Holism is a concept defined by Alfred Adler, in philosophy the theory implies the "parts of a whole are in intimate interconnection, such that they cannot exist independently of the whole, or cannot be understood without reference to the whole, which is thus regarded as greater than the sum of its parts" [Barney \& Perkinson, 2016, p. 292].

The theory arose from the fact that human ought to protect nature because we depend upon it, because it is beautiful and full of life, because it has intrinsic worth, because of history, ontology, because of its complexity. Or, conceivably we ought to protect nature because of some responsibility we hold, a duty regarding the natural world. One or more of these reasons are 
shared by different theories in environmental ethics. Whichever reason it could be, it is evident that it all involves human's perception, values, and action towards the environment. To this, the human's role and perception will always be an important factor in environmental ethics and conservation.

Human beings are an integral part of nature and are tied to it through a series of interactions and interconnectedness. From an ecological standpoint, Homo sapiens is part of the environment (whole) - its evolutionary success is primarily dependent on factors such as climate, resource availability, and other being within the environment. The biblical book of Genesis also confirms that in the Garden of Eden, God did create the environment, and then placed man as part of it. However, the story highlighted that the environment existed in a perfect state of harmony, as man and animal coexisted without death or threat.

However, in the environment, human, as well as other beings, occupy a position which accounts for its responsibility towards ecological balance. This position within both ontology and ecosystem cannot be taken for granted as there is no way environmental ethics will be fashioned out without alluding to it. Man's role as a part of the whole (environment) and their attitude towards the same, however, has changed with the passage of time. As human existence and the existence of all other species within the environment are now been threatened by human blind technological progress and unrestrained appetites for luxury, profit, and power. It is been claimed that "for modern man, nature has become like a prostitute - to be benefited from without any sense of obligation and responsibility toward her. The difficulty is that the condition of the prostituted nature is becoming such as to make any further enjoyment of it impossible" [Hossein, 1968, p. 18]. Man problem started when he began to think that he could act independently against the harmonious relationship which was inherent in the environment for his own selfish use. He began seeing other beings from an instrumental end.

From these respective, Man envisaged the environment as a storehouse of materials for mere use and exploitation. This dominating and egoistic attitude of man towards nature has now led to the environmental degradation of great magnitude. Since human is a part of the environment and not independent of it, his actions are now affecting every member of the environment; as what affects the parts affects the whole and vice versa. Man is gradually realizing his misdeeds and fallacious treatment of nature and therefore seeks a drive to solve the crisis.

In this regard, it is very necessary for man to change his attitude towards the environment. Human has been the cause; however, the same human will be the solution. There is no new theory needed, other than re-imbibing an attitude of respect for nature and understanding that he is just a mere part of the whole (Anthropo-holism). It is therefore high time for human beings to realize and be conscious that he is a part of the biotic community and every member of that community, be they plants, animals, insects or birds have a right to survive and deserve respect from every other member of the community. But one thing which must be remembered is that all species of the biotic community survive through the prey-predator relationship amongst them. It is a natural process and therefore has to continue. Thus, it should be taken for granted that human beings to a certain degree are predators, i.e. they are dependent on other species for their survival. This role of predatorship of human beings is permissible as far as their survival is concerned but not beyond that, as long as it does not translate to egoist and dominating tendencies. Human beings, apart from being a predator for their survival, need to act justly and humanly towards all other species of the biotic community. What ought to be our attitude towards nature can be put down in the following manner:

“... if we can bring ourselves fully to admit the independence of nature, the fact that things go on in their own complex ways, we are likely to feel more respect for the ways in which they go on. We are prepared to contemplate them with admiration, to enjoy them sensuously to study them in their complexity as distinct from looking for simple methods of manipulating them" [Passmore, 1995, p. 141]. 
To develop such an attitude nature, Man must see the environment as something less "strange" which could enable human to be concerned or take interest or even care for it.

From the above reasoning, anthropoholism can be defined as a theory in environmental ethics that acknowledges man (anthropo) central role; perspective, place in eco-system as well as ontology but avers that Man is just a part of nature, such that he cannot exist independently of the environment, or cannot be understood without reference to the environment (holism).

\section{Problem with anthropocentric environmental ethics}

Many environmental philosophers point to anthropocentrism as the major cause of our environmental troubles. The term anthropocentrism comes from the Greek phrase "Anthropos" and "kentron". "Anthropos" means "human being" and "kentron" means "center" [Ascott, 2009]. Inferring from it etymologically, anthropocentrism means human-centredness. However, this definition has been improved upon over time by different scholars to reveal different variant.

Aldo Leopold and his supporters hold that anthropocentrism is unacceptable as a source for an environmental ethic because it unavoidably leads to the exploitation of nature; it also turns nature into a means of satisfying trivial human desires [Frierson, 2013]. Anthropocentrism is also discarded by Tom Regan, Peter Singer and others in the animal liberation movement [Remele \& Tutu, 2013]. They often argue that it is simply an unwarranted prejudice or bias, analogous to racism or sexism, which cannot be rationally defended. To them all, anthropocentrism is rooted in supremacy attitude towards nature, which is the major reason for our ecological problem. This criticism is also shared by many environmentalist worldwide echoing same sentiments. Nevertheless, the difference variance of anthropocentrism shades more light on what is actually wrong with the theory.

Bryan G. Norton articulate two versions of anthropocentrism, which he called; weak and the other strong anthropocentrism [Norton, 2005]. For Norton, the "weak anthropocentrism" necessitates that human beings endeavor to control their decision making process by carefully examining their felt and considered preferences while taking into cognizance a world view derived from sound aesthetic, moral ideals, sound scientific theories as well as a metaphysical framework that interprets these theories [Norton, 2005]. The keywords within this definition are "human" and "control". These keywords acknowledge "human" at the center of the decision-making process while also attempting to "control" his/her biases against other beings within the environment. To this, weak anthropocentrism seems to be environmental friendly based on its mutual consideration as well as tolerance with other beings in the environment. Light and Rolston III echo the same sentiment when they aver that "weak" anthropocentrism or stewardship is using a human-centered perspective to indirectly conserve and protect the natural environment [Light \& Rolston III, 2003].

The use of the adjective "weak" further suggests that there exists a version called, strong anthropocentrism which is typified by uncontrolled destruction and exploitation of nature to serve the human interest. This implies that strong anthropocentrism transgresses from mere man-centered perceived perspective to egoistic and dominating perspective; hereby perceiving other beings within the environment as mere instrumental end to human. Many human practices, like the destruction of habitats, cruelty to animals, endangered species, and disturbing eco-systemic balances are now being criticized based strong anthropocentrism. From the above analysis, it is evidence that the problem with anthropocentrism in environmental ethics lies with the strong version because of its egoistic, supremacy and dominating tendencies towards the environment and not weak anthropocentrism.

To support the above statement, it is important to note that our mentality about the world is limited and shaped by our position and way of being within it. From the angle of any particular being or species in the environment, there are some respects in which they are at the center of it. This is what Frederick Ferré called "perspectival anthropocentrism" [Crowther, 2019, p. 239], which is a version of weak anthropocentrism. 
It appears to be inescapable, unavoidable that we as human should be interested in ourselves and our own species think like humans and see things through human eyes. Ferré in supporting this view writes, "We have no choice but to think as humans, to take a human point of view even while we try to transcend egoism by cultivating sympathy and concern for other centres for intrinsic value" [Crowther, 2019, p. 239]. Also, Mary Midgley avers, "We need $<\ldots>$ to recognize that people do right, not wrong, to have a particular regard for their own kin and their own species $\langle\ldots\rangle$ I don't, therefore, see much point in disputing hotly about the rightness of 'anthropocentrism' in this very limited sense" [Midgley, 1994, p. 111]. Mary Anne Warren also avers that:

"We are not gods but human beings, reasoning about how
we ought to think and act. Our moral theories can only be
based upon what we know and what we care about, or
ought to care about. If this makes our theories
anthropocentric, then this much anthropocentrism is
inevitable in any moral theory that is relevant to human
actions" [Warren, 1997, p. 43].

From the above argument, it is evidence that it is a needless attempt to wipe out any level of "selfhood" from environmental ethics altogether; because what is inevitable about "weak anthropocentrism" is precisely what makes ethics possible. It is a basic element of obligation: if a particular ethics requires a being to accommodate other beings into consideration, if an ethic is a guide to action, then they become the beings own ends. This becomes a limitation on any attempt to construct completely non-anthropocentric ethics. To explain this in simple terms Hayward asserts that, "Values are always the values of the valuer" [Hayward, 1997, p. 51].

In support to this, Norton and Hayward argue differently that the inevitability of a human reference point makes it impossible to create a totally non-anthropocentric value system that has no basis in the human experience and existing human values. The notion that values can simply be recognized and selected without any need to refer to human interpretation is a delusion. Even the natural balance advocated by eco-centrism is a human perception of what balance ought to look like. One perspective of balance might also be that human beings do not interfere in the workings of nature so that nothing will be disturbed.

It is important to note that it is only on "weak anthropocentrism" that we can situate anthropocentric environmental ethics which requires human to act responsibly towards the environment for man's sake. However, one problem with anthropocentrism is how to maintain the weak version and not make it transgress into strong anthropocentrism. This is the major reasons for Socrates assertion "Man know thyself". Which is to say, understanding and control of oneself, leads to a possible mastery and development of self for the promotion of self, others, society and the environment at large. In addition, the imperative of ibuanyidanda philosophy demands that we as human should: "Allow the limitations of being to be the cause of your joy" [Asouzu, 2005, p. 281]. Since existential human nature is said to be ambivalence, adhering to the warning of those two moral philosophers can help tame this irrational element of the egoistic and supremacy tendencies of strong anthropocentrism.

Furthermore, to support weak anthropocentrism postulations, it is widely accepted that self-love can be considered a precondition of loving others, as such; nobody can give what he or she does not have. The biblical scripture "love your neighbor as yourself" [Haas, 2005] further highlight this claim. All these considerations are not projected to show that anthropocentrism is not a problem at all; rather they lead us to spell out more carefully what is wrong to hold a "strong anthropocentric" mindset and not "weak anthropocentric" mindset.

This is the major reason while the theory of "anthropoholism" takes cognizance of man's (anthropo) central role both as a reference point, as the center of ontology and ecosystem while also alluding to holistic environmental ethics. However, weak anthropocentrism and "anthropoholism" are two different theories altogether, but both views share some similarities. While "weak anthropocentrism" attempts to consider human preferences while taking into 
consideration ethical, aesthetic and scientific theories as well as metaphysical framework in fashioning environmental ethics, it does not necessarily imply holistic philosophy. "Anthropoholism" on the other hand takes a holistic approach; all species-being, animate as well as inanimate, including man is considered to be the integral part of the environment, interdependence on one another and cannot exist without the environment as a whole.

Also, Anthropoholism does not necessarily consider moral worldview as a reason for man's responsible behavior towards the environment as in the case of "weak anthropocentrism". Anthropoholism attempts to explain the actual interconnectedness and interdependence of man with nature, this as such should be the driving rationale behind man's endeavor as far as the environment is concerned. This is because Man is one with nature, not over nature and not supreme over nature. Nevertheless, both "weak anthropocentrism" and "anthropoholism" sees human at a central stage of thought process, decision making as well as the eco-system.

From the aforementioned, it is evidence that "anthropoholism" as a theory seeks to bridge the gap between anthropocentric views as well the holistic views in other to solve the long-lasting debates between the anthropocentric and non-anthropocentric environmental ethicists. Even within African holistic environmental ethics, it is acknowledged that man is at the center of the ecosystem as well as ontology, while still maintaining its holistic view. The understanding of man's center position can help human live responsibly within the environment since this position demands a sense of duty and responsibility. This can even foster what I called "environmental nationalism".

Also, strong anthropocentric assumptions have now gradually been challenged by the findings of the modern science of ecology, which challenges humans' distinct and supremacy mentality within the environment, explaining man to be a product of natural evolutionary processes. These researches point to the fact that all being within the environment is related to each other and that we have a crucial interdependence with each other.

The arguments possess above suggest that the aim of fully overcoming anthropocentrism in environmental ethics will be a futile one. The proposals for a total rejection of human-centeredness are not helpful as this could miss the real problem which is in strong anthropocentrism; having a supremacy mentality as well as dominating tendencies against other beings.

\section{African Environmental Ethics (Holistic Environmental Ethics)}

Many scholars have developed some important views about rejecting strong anthropocentric attitude and adopting holistic environmental ethics. For this reason, many African environmental scholars began explaining African environmental ethics from African communitarian perspective which is sometimes referred to as; holistic environmental ethics. Holistic environmental ethics is viable environmental ethics as it preaches interdependence and interconnectedness of humans and nature. From Christian perspective, in the book of Genesis, God created Adam and Eve and placed them in the Garden of Eden, where they lived in harmony with nature until they disobeyed God's instruction and ate the forbidden fruit. This shows that the interconnectedness and interdependence of humans and nature is not only unique to traditional Africa societies, it is also evident in the Christian God original intention. Nevertheless, Africans have been said to be deeply communal; this implies that they acknowledged the interconnectedness and interdependence of humans to human (in a community setting) and Man to nature (in an environmental setting).

African communalism can simply be understood using Mbiti's statement "I am because we are since we are therefore I am" [Mbiti, 1970, p. 35]. What Mbiti means here is that the reality of the community takes precedence over the reality of individual life. Relating this communal position to environmental ethics, it therefore means, the environment takes precedence over "individual" or "individual of persons". That is, without the environment, the individual cannot be. Menkiti, went further down to aver that the community takes epistemic and ontological precedence over the individual [Menkiti, 1984, p. 170]. From the logic of both 
Menkiti's and Mbiti, the individual must of necessity be subject to the normative power of the community (in this case environment) and is thus not seen as the primary reference point for moral actions.

From both Mbiti and Menketi's view, it seems the African system of thought rejects every form of "individualism". However, it is true that we cannot isolate ourselves outside the community and environment at large, that individuals are largely interdependence, and that the moral self develops within a social context where culture and history play crucial roles. However, the self is important because it is through individual self-perspective (perspectival anthropocentrism) that communitarian views can be foster.

This view is also shared by Gyekye's version of communitarian which he called "moderate communitarianism" [Gyekye, 2003, p. 42]. In moderate communitarianism, Matolino argues that Gyekye accuses both Mbiti and Menketi for failing to accommodate the rights and freedom of individuals within the community [Matolino, 2008, p. 75]. Accordingly, Gyekye regards Mbiti and Menkiti's version as radical and philosophically indefensible. In his moderate communitarianism, Gyekye sees the community as a reality in itself and not as a mere association of individuals. He, however, stresses that individual right and capacities should be recognized for they define who a person is. But he carefully concedes that these capabilities should be realized within the context of a community [Gyekye, 1997, p. 49]. However, it is evidence that Gyekye saw the mistake and misinterpretation of many holistic scholars on not recognizing the importance of the "individual" within a holistic/communal thought system. Gyekye's position is very vital as it provides a strong case for "Anthropoholism".

From the aforementioned communal background, many African environmental ethicists took the communal values inherent in African communalism to explain African environmental ethics. For instance, Tangwa describes it as eco-bio-communitarianism against the western perspective he called anthropocentric, Segun Ogungbemi called African traditional ethics "ethics of care" and later proposed "ethics of nature relatedness", while Mogobe B. Ramose called it ecology Ubuntu et cetera. The driving rationale behind these postulations is to show the importance of African communal value to environmental ethics.

Why does African communitarianism correspond to environmental ethics? This is because it is a theory that reflects African thought and worldview. It is hinged on aspects such as the holistic approach, African morality, African traditional religion, African ontology, the idea of the common good, respect for nature and more importantly the interdependence and harmonious relationship between Africans and the environment. Tangwa had summed it up when he avers that within the African worldview, the distinction between plants, animals, and inanimate things, between the sacred and the profane, matter and spirit, the communal and the individual is a slim and flexible one [Tangwa, 2006, p. 389].

This is can also be explained using Ogwuanyi's notion of traditional personification of natural forces and phenomena, in which he states that whatever Africans believe to be the home of sacred spirits, that thing becomes sacred: hills, mountains, rocks, trees, thick forests [Ugwuanyi, 2011]. Kaoma explains further that Africans believe that God, ancestors and other spirits can manifests in nature [Kaoma, 2010, p. 88]. These show the connection that exists between African religion and the environment. This bond is very significant in the sense that it shapes African people's approach towards nature and further help Africans imbibe what Tangwa called "live and lets live" attitude towards nature. Because of this theological link between beings in African ontology (God, ancestors, man, and other lower forces, i.e. other being in the environment), Africans are careful on how nature is been approached and treated.

For example, since sacred forests are seen as places of memory, it is a taboo to harvest goods from such groves. Doing so is considered an attack on God, ancestors and other spirits. From this perspective, people are likely to conserve nature out of reverence for spiritual forces resident in nature as opposed to instrumental reasons alone. A totemic animal which is identified with each tribe in Africa has taboo attached to it, as such that the locales are forbidden to eat such animal. Infringement of this taboo has some severe implication, which could be a form of 
sickness, diseases or even death. What this entails is that since Africans are religious people, infringement of such a taboo is not an option. It can, therefore, be argued that totemism does not only name or point to a natural relationship that exists between human beings and non-human animals, it also points to a spiritual or rather metaphysical relationship. Creation myths also point to a mutual relationship between humans and non-humans in Africa. However, despite the difference variance of creation myth within African cultures, it is been observed that most creation myths show the connection between God, human, land, animals, mountains, and forests. This cosmic relationship between the supernatural, humans and the environment shaped African people's understanding of traditional religion as well as their encounter with nature and environment at large.

From the aforementioned, it is evidence that African communal and ontology worldview helps African to conserve the environment holistically. Nevertheless, Temples, Mbiti's and many other communal scholars agree that man is at the center of the ontology, although, Mbiti caution that this does not imply that man should harm the natural environment. Rather, the man should seek coexistence with nature. Also, it is also agreed among these scholars that human has a central role within the environment. For instance, Mbiti explains that human is one with nature, able to communicate with nature, responsible toward nature and the chief priests of nature [Mbiti, 2001]. This position is also echoed by Ekwealo who argues that human being's special position is rather more that of a caretaker of the universe, a task which goes with appropriate responsibility and consequences [Ekwealo, 2014, p. 197]. The postulations above are simply an explanation of what Frederick Ferré calls "perspectival anthropocentrism". The details and the explanation above from this African scholars fall into the category of weak anthropocentrism. It is weak anthropocentrism because they admit man's central position to both African ontology and eco-system while advocating for tolerance.

This is the major reason while there has been a lot of confusion surrounding the classification of African environmental ethics. Many have banded it as holistic environmental ethics, due to the interdependence of beings within the environment. To some other, it is another anthropocentric environmental ethics, because it sees man central to both ontology and ecosystem. However, with the theory of "anthropoholism", African environmental ethics can be explained vividly as it accommodates both weak anthropocentricism and well as holistic environmental ethics within its speculation. "Anthropoholism" bridges the gap between long-standing debates between anthropocentric and holistic environmental ethics in environmental discussions. "Anthropoholism" acknowledges human central role within thought process as well as ecosystem and ontology, but admits that human is just a mere part of the environment as such is in mutual interdependence with other beings within the environment and it is only within the environment potentials can be fulfilled.

\section{Conclusion}

This paper has been committed to exposing the source of disagreement between anthropocentricism and holistic environmental ethics within the environmental debates. It is apparent that the disagreement is as a result of the debaters' incoherent, inconsistent and lack of tolerance to accommodate one another within the environmental framework. As shown with the African environmental outlook, both anthropocentricism and holistic views are very important for the articulation of a viable environmental ethics. To propose an explanation, this paper is hinged on the theory of Anthropoholism. The theory of Anthropoholism bridges the gap between the two extreme views. The advantage of Anthropoholism over both anthropocentricism and holistic position is seen in its ability to accommodate both positions. Upholding this thesis of Anthropoholism does not only dissolve the bogus disagreements entailed in the entire debate but more importantly, expose the actual aspect of both perspectives which reveals in simple terms the role of the individual and the environment at larger, their interconnectedness and interdependency. 


\section{REFERENCES}

Ascott, R. (Ed.). (2009). New Realities: Being Syncretic. Proceedings of the IX $X^{\text {th }}$ Consciousness Reframed Conference, Vienna, 2008, July 3-5. Wien: Springer.

Asouzu, I. I. (2005). The Method and Principles of Complementary Reflection in and beyond African Philosophy. Münster: Lit Verlag.

Barney, K. F., \& Perkinson, M. A. (2016). Occupational Therapy with Aging Adults: Promoting Quality of Life through Collaborative Practice. St. Louis; MO: Elsevier.

Crowther, R. (2019). Wellbeing and Self-transformation in Natural Landscapes. Cham: Palgrave Macmillan.

Ekwealo, C. J. (2014). African Environmental Values Expressed through Proverbs. In J. Appleton (Ed.), Values in Sustainable Development (pp. 193-203). Abingdon; New York: Routledge. (Original work published 2004).

Frierson, P. (2013). Metastandards in the Ethics of Adam Smith and Aldo Leopold. Environmental Ethics, 29 (2), 171-191. doi: http://doi.org/10.5840/enviroethics200729219.

Gyekye, K. (1997). Tradition and Modernity: Philosophical Reflections on the African Experience. New York: Oxford University.

Gyekye, K. (2003). Person and Community in African Thought. In P. H. Coetzee \& A. P. J. Roux (Eds.), Philosophy from Africa. Johannesburg: International Thomson Publishing ITP.

Haas, P. J. (2005). Elliot Dorff. Love Your Neighbor and Yourself: A Jewish Approach to Modern Personal Ethics. Philadelphia: Jewish Publication Society, 2003. xvii, 366 pp. AJS Review, 29 (1), 181-183. doi: http://doi.org/10.1017/s0364009405320095.

Hayward, T. (1997). Anthropocentrism: A Misunderstood Problem. Environmental Values, 1 (6), 49-63.

Heidegger, M. (1993). The Question Concerning Technology. In M. Heidegger, Basic Writings (Revised and Expanded Edition). London: Routledge.

Hossein, S. (1968). Man and Nature: The Spiritual Crisis of Modern Man. New Delhi; Bombay; Bangalore; Calcutta; Kanpur: Vikash Publishing House Pvt. Ltd.

Kaoma, K. J. (2010). Ubuntu, Jesus, and Earth: Integrating African religion and Christianity in Ecological Ethics (PhD Thesis). Boston University.

Light, A., \& Rolston III, H. (2003). Introduction: Ethics and environmental ethics. In A. Light \& H. Rolston III (Eds.), Environmental ethics: An anthology (pp. 1-12). Malden, MA; Blackwell Publishing Inc.

Matolino, B. (2008). The Concept of Person in African Political Philosophy: An Analytical and Evaluative study (PhD Thesis). University of KwaZulu-Natal.

Mbiti, J. S. (1970). African Religions and Philosophies. New York: Anchor Books.

Mbiti, J. S. (2001). African Religion and the World Order. In P. M. Mische \& M. Merking (Eds.), Toward a Global Civilisation? The Contribution of Religions (pp. 361-370). New York: Peter Lang Publishing Inc.

Menkiti, I. A. (1984). Person and Community in African Thought. In R. A. Wright (Ed.), African Philosophy: An introduction (pp. 171-181). Lanham: University Press of America.

Midgley, M. (1994). The End of Anthropocentrism? In R. Attfield \& A. Belsey (Eds.), Proceedings of the Conference: Philosopby and the Natural Environment, Royal Institute of Philosophy, Cambridge, 1993, July 20-22 (pp. 103-112). Cambridge: Cambridge University Press. doi: https://doi.org/10.1017/S1358246100006482.

Norton, B. G. (2005). Environmental Ethic and Weak Anthropocentrism. In L. Kalof \& T. Satterfield (Eds.), The Earthscan Reader in Environmental Values (pp. 81-96). London, UK: Earthscan.

Passmore, J. (1995). Attitude to Nature from Environmental Ethics. (R. Eliot, Ed.). Oxford: Oxford University Press.

Remele, K., \& Tutu, D. (2013). Animal Protection And Environmentalism. In A. Linzey (Ed.), The Global Guide to Animal Protection (pp. 68-69). Retrieved from http://www.jstor.org/stable/10.5406/j.ctt2tt9r9. 
Tangwa, G. (2006). Some African Reflection on Biomedical and Environmental Ethics. In K. Wiredu (Ed.), A Companion to African Philosopby (pp. 387-399). Oxford: Blackwell Publishing.

Ugwuanyi, L. O. (2011). Advancing an Environmental Ethics through the African World-view. Mediterranean Journal of Social Sciences, 4 (2), 107-114.

Warren, M. A. (1997). Moral Status: Obligations to Persons and Other Living Things. Oxford: Oxford University Press.

Watts, J. (2018). We have 12 years to limit climate change catastrophe, warns UN. The Guardian. Retrieved from https://www.theguardian.com/environment/2018/oct/08/globalwarming-must-not-exceed-15c-warns-landmark-un-report.

\author{
Bassey Samuel Akpan \\ Post Graduate Student, Department of Philosophy \\ University of Calabar \\ Etta Agbo rd., 540242, Calabar, Nigeria \\ E-mail: samuelbassey15@yahoo.com \\ ORCID: https://orcid.org/0000-0003-1790-4682
}

Article arrived: 12.05.2019

Accepted: 24.06.2019

\title{
«АНТРОПОГОАІЗМ» ЯК АВТЕНТИЧНИЙ ІНСТРУМЕНТ АБАЙАИВОГО СТАВАЕННЯ АО АОВКІААЯ
}

\section{Бассей Самюекь Акпан}

аспірант, фінософський факультет

Університет Ка^абару

вул. Етти Агбоо, 540242, Ка^абар, Нігерія

E-mail: samuelbassey15@yahoo.com

ORCID: https://orcid.org/0000-0003-1790-4682

ВіАтоді, як тваринний світ і Аовкіл^я стали головною етичною проблемою, антропоцентричні типи світогляду вважаються винними в нашому аморальному ставленні АО природи. Ті, хто вважають себе «не-антропоцентристами» або ж «вченими-голістами», зазвичай припускають, що антропоцентричні типи захіАних аксіологій та онтологій віАповіАальні за Аеградацію Аовкіл^я, пов’язану 3 Аіяльністю Аюдини. На відміну віА них, невеличка група філософів-екологів вважає, що антропоцентризм є цілком прийнятним як основа Аля екологічної етики, оскільки АюАський погАяА не може бути повністю елімінований 3 процесу прийняття рішень. Вони часто аргументують свою позицію, стверджуючи зАатність АюАини Аіяти віАповіАально по віАношенню Ао Аовкілля заради самого Аюдства та його майбутніх поколінь. Таким чином, існує постійна напруженість між антропоцентризмом та голізмом, коли кожна сторона намагається витіснити оАна оАну. На мій погАяА, ці крайні погАяАи є однобічними, оскільки їм не вистачає терпимості. Суть пропонованої статті полягає в тому, щоб усунути розрив між даними етичними теоріями за допомогою теорії «антропоголізму». Антропоголізм - це теорія етики довкіл^я, яка визнає центральну роль АюАини, ії перспективи, місце в екосистемі й онтології, але стверджує, що Аюдина, не Аивлячись на таку позицію, є Аише частиною природи, а тому не може існувати незалежно віА довкіл^я і не може бути зрозумілою без віАсилання до нього. Таким чином, теорія антропоголізму здатна подолати розрив між антропоцентризмом і голізмом, констатуючи очевидне та пояснюючи зв’язок між цими Авома крайніми теоретичними позиціями.

Ключові слова: антропоцентризм, антропоголізм, африканський комуналізм, Аовкіл^я.

Стаття надійшла до редакції: 12.05.2019

Схвалено Ао Аруку: 24.06.2019 


\section{«АНТРОПОХОАИЗМ» КАК АУТЕНТИЧНЫЙ ИНСТРУМЕНТ БЕРЕЖНОГО ОТНОШЕНИЯ К ОКРУЖАЮЩЕЙ СРЕАЕ}

\section{Бассей Самуэмь Акпан}

аспирант, философский факультет

Университет Кацабара

ул. Этты Агбо, 540242, Камабар, Нигерия

E-mail: samuelbassey15@yahoo.com

ORCID: https://orcid.org/0000-0003-1790-4682

С тех пор, как животный мир и окружающая среда стали главной этической проблемой, антропоцентричные типы мировоззрения считаются виновными в нашем аморальном отношении к природе. Те, кто считают себя «не-антропоцентристами» или же «учеными-холистами», обычно преАполагают, что антропоцентричные типы западных аксиологий и онтологий ответственны за Аеградацию окружающей среды, связанную с Аеятельностью человека. В отличие от них, небольшая группа философов-экологов считает, что антропоцентризм вполне приемлем в качестве основы Аля экологической этики, поскольку человеческий взгляА не может быть полностью элиминирован из процесса принятия решений. Они зачастую аргументируют свою позицию, утвержАая способность человека действовать ответственно по отношению к окружающей среде раАи самого человечества и его будущих поколений. Таким образом, существует постоянная напряженность межАу антропоцентризмом и холизмом, когда каждая сторона пытается вытеснить Аруг Аруга. На мой взгляА, эти крайние взгАяАЫ явАяются оАносторонними, поскольку им не хватает терпимости. Суть преАлагаемой статьи закАючается в том, чтобы устранить разрыв межАу Аанными этическими теориями с помощью теории «антропохолизма». Антропохолизм - это теория этики окружающей среды, которая признает центральную роль человека, его перспективы, место в экосистеме и онтологии, но утверждает, что человек, не смотря на такую позицию, является Аишь частью природы, а потому не может существовать независимо от окружающей среды и не может быть понят без отсылки к ней. Таким образом, теория антропохолизма способна преодолеть разрыв межАу антропоцентризмом и холизмом, констатируя очевиАное и объясняя связь межАу этими Авумя крайними теоретическими позициями.

Кмючевые слова: антропоцентризм, антропохолизм, африканский коммунализм, окружающая среда.

Статья поступила в редакцию: 12.05.2019

Утверждена к печати: 24.06.2019 